\title{
Relationship between biochemical and photosynthetic traits with Asian soybean rust
}

\author{
TÁSSIA B. DE OLIVEIRA ${ }^{1}$, LEONARDO A. PEIXOTO ${ }^{2}$, PAULO E. TEODORO ${ }^{2}$, AMAURI A. \\ DE ALVARENGA ${ }^{3}$, LEONARDO L. BHERING ${ }^{2}$ and CLARA B. HOFFMANN-CAMPO ${ }^{4}$
}

\author{
${ }^{1}$ Departamento de Fisiologia Vegetal, Universidade Federal de Viçosa, Avenida \\ Peter Henry Rolfs, s/n, Centro, 36570-000 Viçosa, MG, Brazil \\ ${ }^{2}$ Departamento de Biologia Geral, Universidade Federal de Viçosa, Avenida Peter \\ Henry Rolfs, s/n, Centro, 36570-000 Viçosa, MG, Brazil \\ ${ }^{3}$ Setor de Fisiologia de Plantas, Departamento de Biologia, Universidade Federal \\ de Lavras, Avenida Aquenta Sol, 37200-000 Lavras, MG, Brazil \\ ${ }^{4}$ Empresa Brasileira de Pesquisa Agropecuária/EMBRAPA, Rodovia Carlos João Strass, \\ Acesso Orlando Amaral Warta, 86001970 Londrina, PR, Brazil \\ Manuscript received on October 10, 2017; accepted for publication on July 19, 2018
}

\begin{abstract}
ABTRACT
Asian soybean rust (Phakopsora pachyrhizi - ASR) is one of the major diseases that occur in soybean and causes great damage to commercial crops. Therefore, the goal of this work was to investigate the relationship between biochemical and photosyntetic parameters in soybean with ASR. Two experiments were performed in a randomized complete block with three treatments (water, Tween 20, and methyl jasmonate). The evaluated traits were: severity, chlorophyll pools, concentration of phenolic compounds content, enzyme activity, and photosyntetic parameters. Based on Pearson correlation, correlation network and path analysis it was verified that the severity had high correlation with almost all traits evaluated meanwhile photosynthesis is weakly related with almost all traits. Therefore, the occurrence of ASR affects directly the traits related to enzymatic activity and phenolic compounds content in soybean plants inoculated with ASR. The management of ASR is important to keep in normal levels the rates of photosynthesis carried out by the plant, and thus not affect the yield. Besides that, understanding the biochemical mechanisms and ecophysiological responses that occur during the soybean- $P$. pachyrhizi interaction has a great importance for breeding programs, as it will help for obtaining resistant cultivars or efficient methods in fungus control.
\end{abstract}

Key words: correlation network, Glycine max, path analysis, Phakopsora pachyrhizi.

\section{INTRODUCTION}

Soybean [Glycine $\max (\mathrm{L}$.$) Merril] currently$ represents one of the main export products of Brazilian agribusiness, contributing significantly to the trade balance, being the culture that has grown

Correspondence to: Leonardo Lopes Bhering

E-mail: leonardo.bhering@ufv.br most in the last three decades. Soybean production worldwide in the 2015/2016 harvest was 312 million tons in a cultivated area of 119 million hectares (USDA 2017). In Brazil, soybean production in the 2015/2016 harvest was 95 million tons in an area of 33 million hectares (CONAB 2017). Parallel to this growth, it is worth mentioning the increase in phytosanitary problems affecting this crop, with 
more than 100 species of pathogens being reported, of which about 35 are of great economic importance (Dorrance et al. 2003).

Among these diseases, Asian soybean rust (ASR), caused by the biotrophic fungus Phakopsora pachyrhizi H. Sydow \& Sydow, is considered a serious problem for agribusiness in soybean producing countries (Goellner et al. 2010). Its rapid expansion and high potential for causing losses in soybean have made this disease one of the main diseases of the crop, which can reach levels that make harvesting inviable (Yorinori et al. 2005). Although chemical control is the most used measure to manage ASR, the indiscriminate use of agrochemicals causes irreversible damage to the environment, causing environmental imbalance and favoring the selection of new physiologically resistant races. Another way of handling ASR is the use of phytoregulators such as methyl jasmonate that stands out as a signaling compound that activates plant defense mechanisms in response to stresses, such as symptoms caused by pests and pathogens (Browse 2009). Jasmonate still plays an important role in the regulation of the expression of genes encoding stress-related proteins (Ruiz-Garcia and Gômez-Plaza 2013). Besides the management forms mentioned above, genetic breeding is a suitable alternative for the management of ASR using resistant varieties.

For the plant breeder to identify tolerant soybean varieties for ASR, it is first necessary to know the association between characters, especially if the selection in one of them presents difficulty due to the low heritability and/or difficulty in the measurement. Thus, the estimates of the correlation coefficients allow to evaluate the magnitude and direction of the relation between two characters, and consequently obtain gains for one of them through the indirect selection using the other character. In some cases, indirect selection, based on the correlated response, can lead to progress faster than the direct selection of the desired variable (Cruz et al. 2012).

Despite the great utility of correlation coefficients for a better understanding of the relationships between variables, they only estimate the association between variables and do not allow conclusions about cause and effect relationships. Studies about the correlation coefficient split are done by path analysis, developed by Wright (1923). This analysis consists of the study of the direct and indirect effects of characters on a main variable, whose estimates are obtained by means of regression equations, in which the variables are previously standardized (Cruz et al. 2012, Vencovsky and Barriga 1992).

In the literature there are few studies that report the association between biochemical and physiological variables with components related to gas exchange and the occurrence of ASR. Therefore, the goal of this work was to investigate the relationship between biochemical and photosyntetic parameters in soybean with ASR.

\section{MATERIALS AND METHODS}

\section{EXPERIMENTAL DESIGN}

Two experiments were performed in a greenhouse at Embrapa Soja in the Warta District, in Londrina, Parana State. Soybean plants of BRS 361 genotype, considered susceptible to ASR, were used. Seeds were obtained from Embrapa Soja Germplasm Bank. The plants were kept in greenhouse (relative humidity $65 \%, 28{ }^{\circ} \mathrm{C}$ ) until the V5 stage (Fehr et al. 1971) and then submitted to the exogenous application of the different products using pressurized sprayer with $\mathrm{CO}_{2}$.

The experiments were set up in a randomized block design with three treatments (water, Tween 20 e methyl jasmonate) with six replications, and each experimental plot consisted of a pot containing five plants. It was not observed interaction between experiments, then it was used the mean between 
experiments to perform the statistics analysis in this study.

\section{CHEMICALS USED}

The products used were: water as a control treatment; the surfactant (Tween 20 - Polyoxyethylene 20 sorbitan monolaurate) at the concentration of $0.02 \%$; and methyl jasmonate (MJ) at the concentration of $1.25 \mathrm{mM}$ prepared in $0.02 \%$ Tween 20 (MJ + T20).

Plants treated with MJ were kept in another greenhouse for 48 hours under the same temperature and humidity conditions to avoid induction in the control plants (Water and Tween 20), since MJ is known as a volatile regulatory phyto (Seo et al. 2001).

\section{PLANTS INOCULATION WITH P. pachyrhizi}

After 24 hours of spraying the products described above, the plants were inoculated. To prepare the inoculum of $P$. pachyrhizi the fungus was previously kept in the cultivar BRS 316, in a greenhouse, at Embrapa Soja. The spores were collected with light beats on the leaves with uredinospores with pustules, on white paper and packed in microtubes. Then, a suspension was prepared with distilled water containing $0.01 \%$ Tween 20 , and adjusted to a final concentration of $1.4 \times 10^{5}$ urospores/ $\mathrm{ml}$. After inoculation, the plants were kept under nebulization to stimulate the infectious process as it requires a high temperature, $23{ }^{\circ} \mathrm{C}$ to $25{ }^{\circ} \mathrm{C}$ and relative humidity greater than $95 \%$ in the absence of light for 12 hours.

\section{EVALUATION OF ASR SEVERITY}

ASR severity was evaluated 16 days after plant inoculation in V2 leaves, using a scale proposed by Godoy et al. (2006). This scale takes into account the percentage of infected leaf area and ranges from $0.6 \%$ to $78.5 \%$.

\section{EVALUATION OF ENZYMATIC ACTIVITY}

To determine the activity of the enzymes chitinase (CHI) and $\beta$-1,3-glucanase (GLU), leaves in the V4 and V5 stages were collected, using two plants per sample. The samples were collected at 48, 96, 144 and 192 hours after inoculation (hai). Leaves of non-inoculated plants were also collected in the same period. The samples were stored individually in aluminum foil and immediately frozen in liquid nitrogen and stored in ultra-freezer at a temperature of $-80{ }^{\circ} \mathrm{C}$. From each leaf extract obtained, enzymatic trails were performed in triplicate.

The activity of CHI and GLU was determined. The total protein concentration in each sample was determined following the method of Bradford (1976).

The foliar extract was obtained by maceration of $0.3 \mathrm{~g}$ of leaf tissue crushed in a liquid nitrogen mortar with addition of $2 \%(\mathrm{p} / \mathrm{v})$ polyvinylpolypyrrolidone (PVPP). The obtained powder was homogenized in $2 \mathrm{~mL}$ of $50 \mathrm{mM}$ sodium phosphate buffer (pH 6.5) and $1 \mathrm{mM}$ phenylmethylsulfonyl fluoride (PMSF). The homogenate was centrifuged at $20,000 \mathrm{x} \mathrm{g}$, at $4{ }^{\circ} \mathrm{C}$ for $25 \mathrm{~min}$. The supernatant was used to determine the enzymatic activity.

$\mathrm{CHI}$ activity was determined according to the method proposed by Roberts and Selitrennikoff (1988) modified by Harman et al. (1993), using as substrate p-nitrophenyl- $\beta-D-N, N$ 'diacetylchitobiose. The incubation system consisted of adding a $20 \mu$ Laliquot of the supernatant obtained as described above, to a mixture containing $470 \mu \mathrm{L}$ of $50 \mathrm{mM}$ sodium acetate buffer $(\mathrm{pH} 5.0)$ and $10 \mu \mathrm{L}$ of PVPP $\left(2 \mathrm{mg} \mathrm{mL}^{-1}\right)$ and maintained at $37{ }^{\circ} \mathrm{C}$ for 2 $\mathrm{h}$. The reaction was paralyzed by adding $0.5 \mathrm{~mL}$ of $0.2 \mathrm{M}$ sodium carbonate and the absorbances was determined at wavelength $410 \mathrm{~nm}$. To calculate the enzymatic activity was used the molar extinction coefficient of $7 \times \mathrm{mM}^{-1} \mathrm{~cm}^{-1}$ with the activity of $\mathrm{CHI}$ expressed in $\mathrm{mM}$ of $\mathrm{p}$-nitrophenyl produced by $\mathrm{min}^{-1} \mathrm{mg}^{-1}$ protein. 
GLU activity was determined according to the method described by Lever (1972), with modifications: 3,5-dinitrosalicylic acid (DNS) to replace p-hydroxybenzoic acid hydrazide (Miller 1959). The reaction consisted of $230 \mu \mathrm{L}$ of 100 $\mathrm{mM}$ sodium acetate buffer ( $\mathrm{pH} 5.0$ ), $250 \mu \mathrm{L}$ of the laminarin substrate solution $\left(4 \mathrm{mg} \mathrm{mL}^{-1}\right)$ and $20 \mu \mathrm{L}$ of the plant extract. The system was incubated at 45 ${ }^{\circ} \mathrm{C}$ for $30 \mathrm{~min}$, and after this period $1 \mathrm{~mL}$ of DNS was added to the reaction and then this mixture was heated at $100{ }^{\circ} \mathrm{C}$ for $5 \mathrm{~min}$. After cooling on ice to $30{ }^{\circ} \mathrm{C}$ the absorbance of the samples was determined at $540 \mathrm{~nm}$ and the results are expressed as absorbance units per $\min ^{-1} \mathrm{mg}^{-1}$ protein.

\section{ANALYSIS OF PHENOLIC COMPOUNDS}

The samples were composed of a V5 leaf collected 48, 96 and 144 hai. Leaves of not inoculated plants were also collected in the same periods. The samples were stored individually in aluminum foil packaging in liquid nitrogen and stored in a freezer $\left(-20{ }^{\circ} \mathrm{C}\right)$ until extraction and analysis, which were performed according to the standard methodology of Laboratório de Química e Ecologia of EMBRAPA Soja, described below.

At the time of extraction, the leaves were crushed in a liquid nitrogen mortar and placed in a Falcon tube. Subsequently, the leaves were weighed $(500 \mathrm{mg})$, and $5 \mathrm{~mL}$ of $90 \%$ methanol was added, and the solution was then subjected to the ultrasonic bath for $20 \mathrm{~min}$. Then the samples were centrifuged at $9,880 \times \mathrm{g}$ at $4{ }^{\circ} \mathrm{C}$ for $12 \mathrm{~min}$, vacuum dried, resolubilized in $1.5 \mathrm{~mL}$ of $80 \%$ methanol and homogenized manually. And then, the plant extracts were filtered through a $0.45 \mu \mathrm{m}$ Millipore ${ }^{\circledR}$ membrane and transferred to tubes of the automated sampler and analyzed HPLC (High Performance Liquid Chromatography) - Shimadzu - Prominence model.

The methanolic extracts from the samples were analyzed on C18 column $(250 \mathrm{~mm}$ long and $4.6 \mathrm{~mm}$ internal diameter, $5 \mu \mathrm{M}$ particles). Aliquots of $10 \mu \mathrm{L}$ were injected automatically into the equipment, with CBM-20 a controller, SPD20A detector, DGU 20A5 degasser, LC-20AT pump, SIL-20A automatic sampler and CTO 20A furnace. The mobile phase was composed of two solvents: (A) 2\% acetic acid (HOAc) and (B): A mixture of methanol, acetic acid and MilliQ ${ }^{\circledR}$ water $\left(\mathrm{MeOH}: \mathrm{HOAc}: \mathrm{H}_{2} \mathrm{O} ; 18: 1: 1\right)$. The linear gradient system used in the analysis started from the initial condition with $75 \%$ of A and $25 \%$ of B reaching, and after $40 \mathrm{~min}$, the inverse situation, in other words, $25 \%$ of A and $75 \%$ of B, where it was maintained during $5 \mathrm{~min}$. At $45 \mathrm{~min}$, it returned to the initial situation, remaining for $5 \mathrm{~min}$, before the next injection. The solvent flow was $1 \mathrm{~mL} \mathrm{~min}^{-}$ ${ }^{1}$ and ultraviolet region analysis was obtained at wavelength 260 and $280 \mathrm{~nm}$.

The concentrations of the isoflavonoid aglycones (genistein - GEI in $\mu \mathrm{g} \mathrm{g}^{-1}$ ) of 7-O-glycosidic forms (daidzin - DZI in $\mu \mathrm{g} \mathrm{g}^{-1}$, and genistin - GI in $\mu \mathrm{g} \mathrm{g}^{-1}$ ), of malonyl glycosidic (6"-O-malonyldaidzin - MD in $\mu \mathrm{g} \mathrm{g}^{-1}$, and 6"-O-malonylgenistin - MG in $\mu \mathrm{g} \mathrm{g}^{-1}$ ), of flavonoid rutin (quercitin 3-O-rutinoside - $\mathrm{R}$ in $\mu \mathrm{g} \mathrm{g}^{-1}$ ) and of phytoalexin coumestrol $\left(\mathrm{C}\right.$ in $\left.\mu \mathrm{g} \mathrm{g}^{-1}\right)$ were identified by comparing spectrum and retention time of the patterns with the spectrum and retention time of each sample analyzed.

The peak area of each identified substance was measured and multiplied by the correction factor of each standard compound, taking into account the initial tissue mass and volume of resolubilization. In order to obtain the correction factor of each compound, different concentrations of isoflavones and phenolic acids standards $(6.25,12.5,25,50$, $100 \mu \mathrm{g} \mathrm{mL}^{-1}$ ) were injected into the HPLC. From the values of the areas of the standard compounds and their concentrations, a dispersion graphic was constructed and a linear regression equation and its correction factor was obtained. 
EVALUATION OF PHOTOSYNTETIC PARAMETERS AND CHLOROPHYLL POOLS

Evaluations of photosyntetic parameters and chlorophyll pools were performed on central V4 leaflets, previously marked at 39, 87, 135 and 183 hai, between 9 and 10 o'clock in the morning. A portable photosynthesis analyzer was used, model LCpro-SD of ADC brand. Active photosynthetic radiation of $1044 \mu \mathrm{mol} \mathrm{m} \mathrm{m}^{-2} \cdot \mathrm{s}^{-1}$ was used. The following physiological parameters were evaluated: $C_{i}$ - internal $\mathrm{CO}_{2}$ concentration; $E$ - transpiration rate; $\mathrm{G}_{\mathrm{s}}$ - stomatal conductance to water vapor; $A$ net $\mathrm{CO}_{2}$ assimilation rate.

The chlorophyll pools was determined indirectly through the SPAD index, using the chlorophyllometer SPAD-502. From the SPAD index obtained in the chlorophyllometer, the total chlorophyll pools was calculated using the equation described below, which was generated in calibration and validation tests performed at Embrapa Soja (Unpublished data):

$$
\mathrm{CC}=((\mathrm{SPAD} * 0,0007)-0,0071)
$$

Where CC is the chlorophyll pool expressed in mg.cm ${ }^{-2}$.

\section{STATISTICAL ANALYSIS}

Initially, analysis of variance (ANOVA) was performed for each character according to the statistical model described below:

$$
\mathrm{Y}_{\mathrm{ij}}=\mu+\mathrm{B}_{\mathrm{j}}+\mathrm{T}_{\mathrm{i}}+\mathrm{e}_{\mathrm{ij}}
$$

Where: $Y_{i j}$ is the observation in the $\mathrm{j}$-th block, evaluated in the $i$-th treatment; $\mu$ is the overall mean of the experiment; $B_{j}$ is the fixed effect of the $j$-th block; $T_{i}$ is the fixed effect of the $i$-th treatment; $e_{i j}$ is the random error associated with observation $Y_{i j}$.

Tukey test was performed to verify significant statistic difference among treatments. Subsequent, the phenotypic correlations $\left(r_{p}\right)$ between the pairs of characters were estimated according in the equation below:

$$
r_{p}=\frac{\operatorname{COV}_{\mathrm{P}(\mathrm{xy})}}{\sqrt{\hat{\sigma}_{\mathrm{Px}}^{2} \times \hat{\sigma}_{\mathrm{Py}}^{2}}}
$$

Where: $\operatorname{COV}_{\mathrm{P}(\mathrm{xy})}$ is the phenotypic covariance between the variables $\mathrm{X}$ e $\mathrm{Y}$; $\hat{\sigma}_{\mathrm{PX}}^{2}$ is the phenotypic variance of the variable $\mathrm{X} ; \hat{\sigma}_{\mathrm{Py}}^{2}$ is the phenotypic variance of the variable Y. Phenotypic correlations were tested by the t-test with n-2 degrees of freedom.

In order to graphically express the functional relation of the estimates of the phenotype correlation coefficients between the variables $\left(r_{i j}\right)$ the correlation network was used, in which the proximity between the nodes (traces) is proportional to the absolute value of the correlation between these nodes. The thickness of the edges was controlled by applying a cut-off value of 0.60 , which means that only $\left|r_{\mathrm{ij}}\right| \geq 0.60$ have their edges highlighted. Finally, positive correlations were highlighted in green, while negative correlations were represented in red.

Subsequently, a multicollinearity analysis of the X'X correlation matrix was performed, which revealed severe multicollinearity (condition number $>1000$ ) according to Montgomery et al. (2015) classification. Therefore, to carry out the path analyzes a constant $\mathrm{k}$ $=0.10$ was added to the diagonal of the $\mathrm{X}^{\prime} \mathrm{X}$ matrix for path analysis, which provided weak multicolinearity (condition number $<100$ ).

Path analysis, considering the SEV and A as main dependent variables, was performed by the model described below:

$$
\begin{gathered}
S E V=\beta_{1} D Z I+\beta_{2} G I+\ldots+\beta_{n} C H I+p_{\varepsilon} \\
A=\beta_{1} D Z I+\beta_{2} G I+\ldots+\beta_{n} C H I+p_{\varepsilon}
\end{gathered}
$$

Where: $\beta_{1}, \beta_{2}, \ldots, \beta_{n}$ are the direct effects estimators of the variables DZI, GI, MD, R, GEI, C, CC, $C, E$, $G_{s}, \mathrm{GLU}$ and $\mathrm{CHI}$ on SEV and $A ; p_{\varepsilon}$ is the residual 
effect of the analysis. Thus, the normal system of equations $X^{\prime} X \hat{\beta}=X^{\prime} Y$ was used to estimate the direct and indirect effects of each explanatory variable on $\mathrm{SEV}$ and $A$, according to the equation described below:

$$
\begin{aligned}
& {\left[\begin{array}{ccc}
1.10 & \cdots & r_{D Z I x C H I} \\
\vdots & \ddots & \vdots \\
r_{C H I x D Z I} & \cdots & 1.10
\end{array}\right] x\left[\begin{array}{c}
\hat{\beta}_{1} \\
\vdots \\
\hat{\beta}_{n}
\end{array}\right]=\left[\begin{array}{c}
r_{\text {DZIXSEV }} \\
\vdots \\
r_{C H I x S E V}
\end{array}\right]} \\
& {\left[\begin{array}{ccc}
1.10 & \cdots & r_{D Z I x C H I} \\
\vdots & \ddots & \vdots \\
r_{C H I x D Z I} & \cdots & 1.10
\end{array}\right] x\left[\begin{array}{c}
\hat{\beta}_{1} \\
\vdots \\
\hat{\beta}_{n}
\end{array}\right]=\left[\begin{array}{c}
r_{D Z I x A} \\
\vdots \\
r_{C H I x A}
\end{array}\right]}
\end{aligned}
$$

The coefficient of determination $\left(\mathrm{R}^{2}\right)$ of the path analysis was obtained by the equation described below:

$$
\begin{aligned}
& R^{2}=\hat{\beta}_{1} r_{\text {DZIXSEV }}+\ldots+\hat{\beta}_{n} r_{\text {CHIISSEV }} \\
& R^{2}=\hat{\beta}_{1} r_{\text {DZIXA }}+\ldots+\hat{\beta}_{n} r_{C H I x A}
\end{aligned}
$$

The residual effect $\left(\hat{\mathrm{p}}_{\varepsilon}\right)$ of the path analysis was obtained by the equation:

$$
\hat{\mathrm{p}}_{\varepsilon}=\sqrt{1}-\mathrm{R}^{2}
$$

All statistical analyzes were performed using the GENES software (Cruz 2013) and followed the procedures recommended by Cruz et al. (2012).

\section{RESULTS}

\section{ANOVA AND ESTIMATES OF GENETIC PARAMETERS}

In order to verify if there was a significant difference between the treatments and to estimate the genetic and experimental parameters, the analysis of variance for the 15 characters was performed. Significant difference was verified for seven traits
(DZI, MD, MG, SEV, $C_{i}$, GLU e CHI), while for the other traits there was no significant difference between the treatments (Table I).

$\mathrm{CV}_{\mathrm{e}}$ higher than $20 \%$ was observed for all phenolic compounds content evaluated, except for MG (Table I). However, the $\mathrm{CV}_{\mathrm{e}}$ for the variables related to photosyntetic parameters and chlorophyll pools, enzymatic activity and severity were low (below 20\%).

The coefficient of determination $\left(\mathrm{H}^{2}\right)$ was high for most of the evaluated variables, except for GI and $\mathrm{R}$, while intraclass correlation was high only for variables DZI, MD, MG, SEV, $C_{i}$, GLU e CHI (Table II).

The quadratic treatment component was high for most of the evaluated variables, while the coefficient of genetic variation was high only for the variables DZI, MD, MG, C, SEV e CHI (Table II).

Based on Tukey test, it was observed that methyl jasmonate was able to reduce ASR effects on soybean plants, decreasing the severity (Table III). In addition the application of methyl jasmonate increased enzymatic activity which GLU increased $25 \%$ and $\mathrm{CHI}$ increased $100 \%$ compared with other treatments. On the other hand, phenolic compunds content decreased with the application of methyl jasmonate such as DZI, GI, MD, MG and C.

\section{PHENOTYPIC CORRELATIONS}

In order to verify the linear relationship between severity, phenolic compounds content, enzymatic activity, photosyntetic parameters, and chlorophyll pools, the correlation between these traits was estimated and the correlation network was used to graphically express these results. It was observed that of the 105 possible correlations 82 (78\%) were considered high (above 0.5), where 42 (40\%) were negative and 40 (38\%) were positive (Table IV).

From the correlation network, it was possible to observe that $A$ was weakly related to almost all 
TABLE I

Mean square of treatment. mean square of residue and F-test estimated by the analysis of variance for 15 traits evaluated in soybean plants inoculated with ASR and their respective coefficients of experimental variation $\left(\mathrm{CV}_{\mathrm{e}}\right)$.

\begin{tabular}{|c|c|c|c|c|c|}
\hline \multirow[b]{2}{*}{ Type } & \multirow{2}{*}{ Traits } & \multicolumn{2}{|c|}{ Mean squares } & \multirow{2}{*}{ Calculated F } & \multirow{2}{*}{$\mathrm{CV}_{\mathrm{e}}(\%)$} \\
\hline & & Treatments & Residual & & \\
\hline \multirow{7}{*}{ Phenolic compounds } & DZI & 1203.73 & 138.81 & $8.67 * *$ & 48.18 \\
\hline & GI & 993.89 & 818.89 & 1.21 & 53.98 \\
\hline & MD & 48251.57 & 980.39 & $49.21 * *$ & 25.39 \\
\hline & $\mathrm{R}$ & 202.23 & 131.78 & 1.53 & 50.49 \\
\hline & $\mathrm{MG}$ & 7451.91 & 344.44 & $21.63 * *$ & 20.36 \\
\hline & GEI & 0.08 & 0.23 & 0.37 & 64.02 \\
\hline & $\mathrm{C}$ & 1.58 & 0.40 & 3.90 & 58.99 \\
\hline Severity & SEV & 2187.08 & 10.14 & $215.57 * *$ & 19.11 \\
\hline \multirow{2}{*}{ Chlorophyll pools } & $\mathrm{CC}$ & $1.10^{-6}$ & $2.10^{-6}$ & 0.32 & 11.17 \\
\hline & $\mathrm{Ci}$ & 891.72 & 54.72 & $16.29 * *$ & 2.00 \\
\hline \multirow{3}{*}{$\begin{array}{c}\text { Photosyntetic } \\
\text { parameters }\end{array}$} & $E$ & 0.01 & $5.10^{-3}$ & 2.70 & 5.04 \\
\hline & $G_{s}$ & $2.10^{-3}$ & $3.10^{-3}$ & 0.66 & 17.22 \\
\hline & $A$ & 4.74 & 1.75 & 2.70 & 13.78 \\
\hline \multirow{2}{*}{ Enzymatic activity } & GLU & 4125.37 & 351.40 & $11.73 * *$ & 14.20 \\
\hline & $\mathrm{CHI}$ & 269.05 & 6.99 & $38.47 * *$ & 17.91 \\
\hline
\end{tabular}

TABLE II

Estimates of the genetic parameters for the 15 traits evaluated in soybean plants inoculated with ASR.

\begin{tabular}{|c|c|c|c|c|c|c|c|}
\hline Type & Traits & $\hat{\sigma}_{\mathrm{P}}^{2}$ & $\hat{\sigma}^{2}$ & $\hat{\sigma}_{g}^{2}$ & $\mathbf{H}^{2}$ & $\mathrm{CV}_{\mathrm{g}}$ & $\mathbf{r}$ \\
\hline \multirow{7}{*}{ Phenolic compounds } & DZI & 200.62 & 23.13 & 177.48 & 88.46 & 54.47 & 56.11 \\
\hline & GI & 165.64 & 136.48 & 29.16 & 17.60 & 10.18 & 3.43 \\
\hline & MD & 8041.92 & 163.39 & 7878.53 & 97.96 & 71.98 & 88.93 \\
\hline & $\mathrm{R}$ & 33.70 & 21.96 & 11.74 & 34.83 & 15.07 & 8.18 \\
\hline & MG & 1241.98 & 57.40 & 1184.57 & 95.37 & 37.77 & 77.47 \\
\hline & GEI & - & - & - & - & - & - \\
\hline & $\mathrm{C}$ & 0.26 & 0.06 & 0.19 & 74.39 & 41.05 & 32.62 \\
\hline Severity & SEV & 364.51 & 1.69 & 362.8 & 99.53 & 114.28 & 97.27 \\
\hline Chlorophyll pools & $\mathrm{CC}$ & - & - & - & - & - & - \\
\hline \multirow{4}{*}{ Photosyntetic parameters } & $C_{i}$ & 148.62 & 9.12 & 139.50 & 93.86 & 3.20 & 71.82 \\
\hline & $E$ & $2.10^{-3}$ & $8.10^{-4}$ & $1.10^{-3}$ & 63.00 & 2.68 & 22.10 \\
\hline & $G_{s}$ & - & - & - & - & - & - \\
\hline & $A$ & 0.79 & 0.29 & 0.49 & 62.98 & 7.34 & 22.09 \\
\hline \multirow{2}{*}{ Enzymatic activity } & GLU & 687.56 & 58.56 & 628.99 & 91.48 & 19.00 & 64.15 \\
\hline & $\mathrm{CHI}$ & 44.84 & 1.16 & 43.67 & 97.40 & 44.77 & 86.19 \\
\hline
\end{tabular}

$\hat{\sigma}_{\mathrm{P}}^{2}$ : phenotypic variance; $\hat{\sigma}^{2}$ : environmental variance; $\hat{\sigma}_{\mathrm{g}}^{2}$ : quadratic component of treatment; $\mathrm{H}^{2}$ : determination coefficient; $\mathrm{CV}$ : coefficient of genetic variation; r: intraclass correlation; DZI - daidzin; GI - genistin; MD - 6"-O- malonyldaidzin; R - rutin; MG - 6"-O- malonylgenistin; C coumestrol; $\mathrm{SEV}$ - severity; $\mathrm{CC}$ - chlorophyll; $C_{i}$ - internal $\mathrm{CO}_{2}$ concentration; $E$ - transpiration rate; $G_{s}$ - stomatal conductance to water vapor; $A$ - net $\mathrm{CO}_{2}$ assimilation rate; GLU - $\beta$-1.3-glucanase; $\mathrm{CHI}$ - chitinase. 
evaluated variables, except for $\mathrm{R}$ and $C_{i}$ (Figure 1). The SEV has significant and positive correlations with DZI and MD, and negative with phenolic compounds content (R, E and GI) and E. Chlorophyll pools has significant and positive correlations with phenolic compounds content (DZI, MD, MG and C) and SEV, and negative with all compounds related to photosyntetic parameters $\left(E, C_{i}\right.$ and $\left.G_{s}\right)$ and enzymatic activity (GLU and CHI). Substances related to enzymatic activity had a significant and high correlation with photosyntetic parameters.

\section{PATH ANALYSIS}

Path analyzes were performed in order to verify how the variables related to phenolic compounds content, enzymatic activity and photosyntetic parameters affect directly or indirectly the main variables (SEV and $A$ ). It was observed that the estimation coefficient was of high magnitude (= 0.98 e 0.97 ) and the residual effect of low magnitude (0.12 and 0.18) for SEV and A respectively (Tables $\mathrm{V}$ and $\mathrm{VI})$.

The highest direct effect on SEV was obtained by the variable R (-0.17) followed by $E(-0.16), A$ (-0.14), GI (-0.14) and GEI (-0.13) (Table V), while for $A$ the variable with the greatest direct effect was $C_{i}(-0.27)$ followed by $\mathrm{R}(0.24), \mathrm{C}(0.18)$, SEV (-0.17) and $E(-0.17)$ (Table VI) considering absolute values.

When we evaluated the indirect effects, it was observed that few of these effects were superior of the residual effect, for both SEV and $A$ (Tables $\mathrm{V}$ and VI). For SEV we can highlight the following indirect effects: GI (0.13) and $E(0.13)$ via DZI; R $(-0.15)$, GEI (-0.13) e $E(-0.15)$ via GI; GI $(0.13)$ and $E(0.14)$ via $\mathrm{MD} ; E(-0.14)$ via R; GI (-0.13), $\mathrm{R}(-0.14)$ and $E(-0.15)$ via GEI; GI (-0.13) and $\mathrm{R}(-0.16)$ via $E ; E(-0.13)$ via $G_{s} ; \mathrm{R}(0.13)$ via $A$ (Table V). For A we can highlight the following indirect effects: $\mathrm{R}(0.18)$ via GI; $C_{i}(0.24)$ via MG; $\mathrm{R}(0.21)$ via $\mathrm{GEI} ; C_{i}(0.25)$ via $\mathrm{C}$; $\mathrm{R}(-0.23)$ via
$\mathrm{SEV} ; C_{i}(0.19)$ via $\mathrm{CC} ; \mathrm{R}(0.23)$ via $E ; C_{i}(-0.19)$ via GLU; $C_{i}(-0.24)$ via $\mathrm{CC}$ (Table VI).

\section{DISCUSSION}

\section{ANOVA AND ESTIMATES OF GENETIC PARAMETERS}

The existence of a significant effect for the treatments of variables DZI, MD, MG, SEV, GLU and CHI showed that inoculation with the $P$. pachyrhizi fungus causes changes in enzymatic activity, phenolic compounds content in soybean plants inoculated with ASR. Thus, understanding the biochemical mechanisms and ecophysiological responses that occur during the soybean $P$. pachyrhizi interaction has a great importance for breeding programs, as it will help for obtaining resistant cultivars or efficient methods in fungus control.

Some of the evaluated phenolic compounds (GI, $\mathrm{R}$ and $\mathrm{C}$ ) presented $\mathrm{CV}_{\mathrm{e}}$ estimates higher than their respective estimates for $\mathrm{CV}_{\mathrm{g}}$. In addition, these traits presented low intraclass correlation estimates. Other variables that presented low intraclass correlation estimates were $\mathrm{E}$ and $\mathrm{A}$. These results indicate that the non-significant effect among treatments occurred due to the absence of correlation between the replicates (low r), which inflated the residual variance and even made it impossible to obtain the genetic parameter estimates for some traits (Cruz et al. 2012) such as GEI, CC and $G_{s}$. From these results it is possible to recommend the use of a greater number of repetitions to evaluate GI, R, GEI, C, CHL, $E, G_{s}$ and $A$ variables in future experiments to increase accuracy in their estimates.

The estimation of $\mathrm{H}^{2}$ makes it possible to know the fraction of the phenotypic variation between treatments that is genetic nature. The high estimates of this parameter for the variables DZI, $\mathrm{MD}, \mathrm{MG}, \mathrm{SEV}, C_{P}$, GLU and $\mathrm{CHI}$ and moderate for $E$ and $A$ are encouraging for breeding programs. 
TABLE III

Mean comparison test among water and methyl jasmonate (MJ) for the 15 traits evaluated in soybean plants inoculated with ASR.

\begin{tabular}{|c|c|c|c|}
\hline Type & Traits & Water & MJ \\
\hline \multirow{7}{*}{ Phenolic compounds } & DZI & $38.24^{\mathrm{a}}$ & $9.93^{b}$ \\
\hline & GI & $63.28^{\mathrm{a}}$ & $38.57^{\mathrm{a}}$ \\
\hline & MD & $213.00^{\mathrm{a}}$ & $33.67^{\mathrm{c}}$ \\
\hline & $\mathrm{R}$ & $16.23^{\mathrm{a}}$ & $24.58^{\mathrm{a}}$ \\
\hline & MG & $108.40^{\mathrm{a}}$ & $50.57^{\mathrm{b}}$ \\
\hline & GEI & $0.62^{\mathrm{a}}$ & $0.86^{\mathrm{a}}$ \\
\hline & $\mathrm{C}$ & $1.29^{\mathrm{a}}$ & $0.49^{\mathrm{a}}$ \\
\hline Severity & SEV & $38.63^{\mathrm{a}}$ & $4.07^{\mathrm{b}}$ \\
\hline Chlorophyll pools & $\mathrm{CC}$ & $0.01^{\mathrm{a}}$ & $0.01^{\mathrm{a}}$ \\
\hline \multirow{4}{*}{ Photosyntetic parameters } & $C_{i}$ & $369.80^{\mathrm{a}}$ & $380.70^{\mathrm{a}}$ \\
\hline & $E$ & $1.34^{\mathrm{a}}$ & $1.43^{\mathrm{a}}$ \\
\hline & $G_{s}$ & $0.32^{\mathrm{a}}$ & $0.36^{\mathrm{a}}$ \\
\hline & $A$ & $9.01^{\mathrm{a}}$ & $9.18^{\mathrm{a}}$ \\
\hline \multirow{2}{*}{ Enzymatic activity } & GLU & $112.50^{\mathrm{b}}$ & $161.80^{\mathrm{a}}$ \\
\hline & $\mathrm{CHI}$ & $11.35^{\mathrm{b}}$ & $22.47^{\mathrm{a}}$ \\
\hline
\end{tabular}

MJ - Methyl jasmonate; DZI - daidzin; GI - genistin; MD - 6"-O- malonyldaidzin; R - rutin; MG - 6"-O- malonylgenistin; C coumestrol; SEV - severity; $\mathrm{CC}$ - chlorophyll; $C_{i}$ - internal $\mathrm{CO}_{2}$ concentration; $E$ - transpiration rate; $G_{s}$ - stomatal conductance to water vapor; $A$ - net $\mathrm{CO}_{2}$ assimilation rate; GLU - $\beta$-1.3-glucanase; $\mathrm{CHI}$ - chitinase. Treatments follow by the same letter did not have statistic difference by Tukey test considering $5 \%$ of probability.

TABLE IV

Phenotypic correlations among the 15 traits evaluated in soybean plants inoculated with ASR.

\begin{tabular}{|c|c|c|c|c|c|c|c|c|c|c|c|c|c|c|c|}
\hline Traits & DZI & GI & MD & $\mathbf{R}$ & MG & GEI & C & SEV & $\mathrm{CC}$ & $\mathbf{C i}$ & $\mathbf{E}$ & $\mathrm{SC}$ & A & GLU & CHI \\
\hline DZI & 1 & -0.94 & 0.99 & -0.68 & 0.84 & -0.96 & 0.80 & 0.88 & 0.96 & -0.48 & -0.87 & -0.99 & -0.04 & -0.95 & -0.85 \\
\hline GI & & 1 & -0.96 & 0.88 & -0.62 & 0.99 & -0.56 & -0.98 & -0.82 & 0.17 & 0.98 & 0.91 & 0.63 & 0.80 & 0.64 \\
\hline MD & & & 1 & -0.71 & 0.81 & -0.97 & 0.77 & 0.90 & 0.94 & -0.44 & -0.89 & -0.99 & -0.09 & -0.94 & -0.83 \\
\hline $\mathrm{R}$ & & & & 1 & -0.19 & 0.85 & -0.11 & -0.94 & -0.46 & -0.30 & 0.95 & 0.62 & 0.75 & 0.44 & 0.23 \\
\hline MG & & & & & 1 & -0.66 & 0.99 & 0.49 & 0.95 & -0.87 & -0.48 & -0.88 & 0.49 & -0.96 & -0.99 \\
\hline GEI & & & & & & 1 & -0.60 & -0.97 & -0.85 & 0.22 & 0.97 & 0.93 & 0.31 & 0.83 & 0.67 \\
\hline $\mathrm{C}$ & & & & & & & 1 & 0.42 & 0.93 & -0.91 & -0.41 & -0.84 & 0.56 & -0.94 & -0.99 \\
\hline SEV & & & & & & & & 1 & 0.72 & -0.02 & -0.99 & -0.84 & -0.50 & -0.70 & -0.71 \\
\hline $\mathrm{CC}$ & & & & & & & & & 1 & -0.70 & -0.71 & -0.98 & 0.22 & -0.99 & -0.96 \\
\hline $\mathrm{Ci}$ & & & & & & & & & & 1 & 0.01 & 0.55 & -0.85 & 0.72 & 0.86 \\
\hline E & & & & & & & & & & & 1 & 0.83 & 0.51 & 0.69 & 0.50 \\
\hline $\mathrm{SC}$ & & & & & & & & & & & & 1 & -0.03 & 0.97 & 0.89 \\
\hline A & & & & & & & & & & & & & 1 & -0.25 & -0.47 \\
\hline GLU & & & & & & & & & & & & & & 1 & 0.97 \\
\hline $\mathrm{CHI}$ & & & & & & & & & & & & & & & 1 \\
\hline
\end{tabular}

DZI - daidzin; GI - genistin; MD - 6"-O- malonyldaidzin; R - rutin; MG - 6"-O- malonylgenistin; C - coumestrol; SEV - severity; $\mathrm{CC}$ - chlorophyll; $\mathrm{Ci}$ - Concentration of intercelular $\mathrm{CO}_{2}$; $\mathrm{E}$ - perspiration; $\mathrm{SC}$ - stomatal conductance; A - photosynthesis; GLU - $\beta$-1.3-glucanase; $\mathrm{CHI}$ - chitinase. 
TABLE V

Estimates of the direct (main diagonal) and indirect effects of the variables on the main variable (SEV evaluated in soybean plants inoculated with ASR.

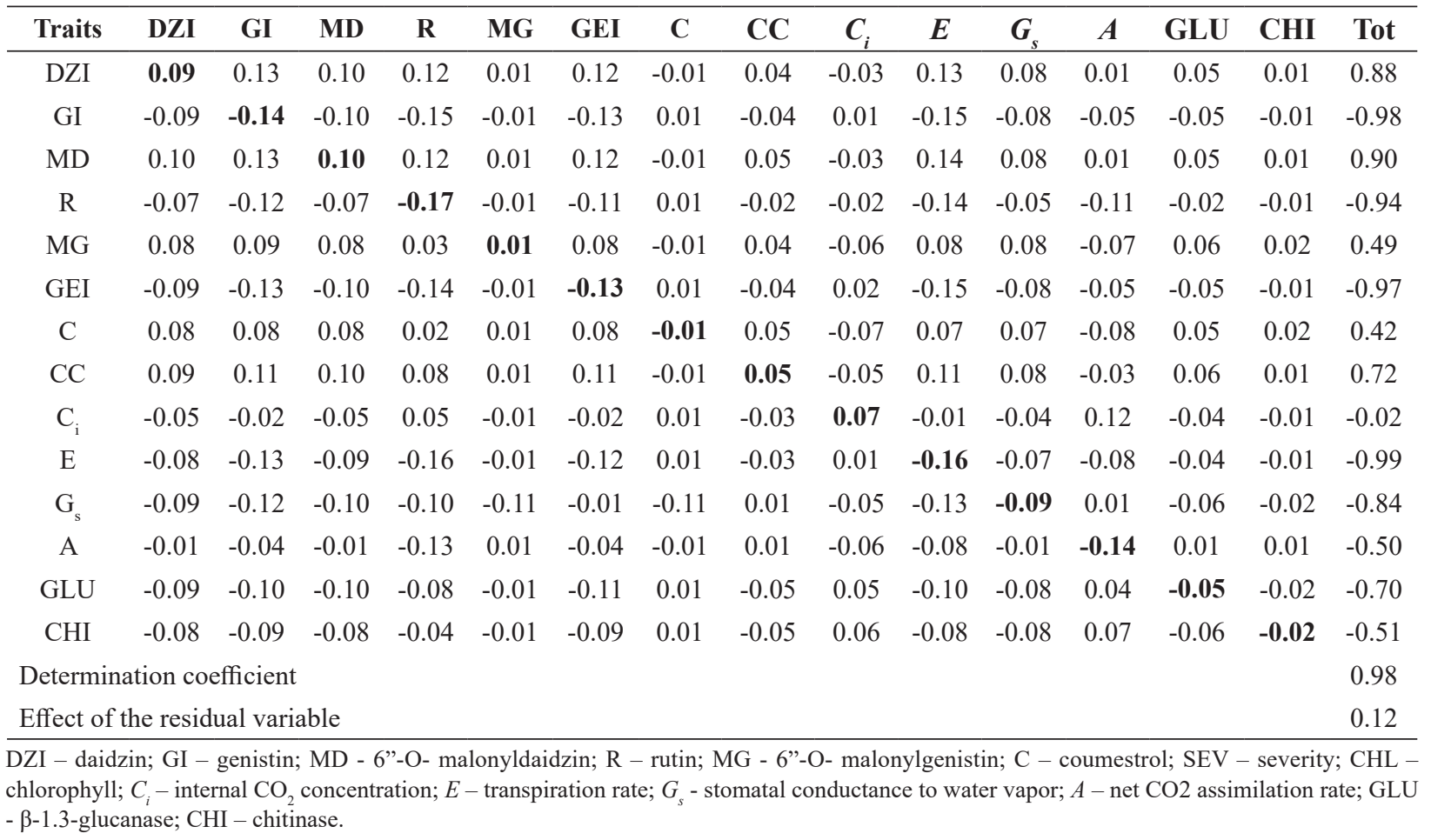

TABLE VI

Estimates of the direct (main diagonal) and indirect effects of the variables on the main variable $\boldsymbol{A}$ evaluated in soybean plants inoculated with ASR.

\begin{tabular}{cccccccccccccccc}
\hline Traits & $\mathbf{D Z I}$ & $\mathbf{G I}$ & $\mathbf{M D}$ & $\mathbf{R}$ & $\mathbf{M G}$ & $\mathbf{G E I}$ & $\mathbf{C}$ & $\mathbf{S E V}$ & $\mathbf{C C}$ & $\boldsymbol{C}_{\boldsymbol{i}}$ & $\boldsymbol{E}$ & $\boldsymbol{G}_{s}$ & GLU & CHI & Tot \\
\hline DZI & $\mathbf{- 0 . 0 2}$ & -0.12 & -0.03 & -0.17 & 0.13 & -0.10 & 0.14 & -0.15 & 0.07 & 0.13 & -0.16 & 0.01 & 0.01 & 0.13 & -0.04 \\
GI & 0.02 & $\mathbf{0 . 1 2}$ & 0.03 & 0.22 & -0.10 & 0.11 & -0.10 & 0.17 & -0.06 & -0.05 & 0.17 & -0.01 & -0.07 & -0.10 & 0.36 \\
MD & -0.02 & 0.12 & $\mathbf{0 . 0 3}$ & -0.18 & 0.13 & -0.10 & 0.13 & -0.15 & 0.07 & 0.12 & -0.16 & 0.01 & 0.08 & 0.13 & -0.09 \\
R & 0.01 & 0.11 & 0.02 & $\mathbf{0 . 2 4}$ & -0.03 & 0.09 & -0.02 & 0.16 & -0.03 & 0.08 & -0.17 & 0.01 & -0.04 & -0.03 & 0.75 \\
MG & -0.01 & -0.07 & -0.03 & -0.04 & $\mathbf{0 . 1 5}$ & -0.07 & 0.17 & -0.08 & 0.07 & 0.24 & -0.08 & 0.01 & 0.09 & 0.16 & 0.49 \\
GEI & 0.02 & 0.12 & 0.03 & 0.21 & -0.10 & $\mathbf{0 . 1 1}$ & -0.11 & 0.16 & -0.07 & -0.06 & 0.17 & -0.01 & -0.08 & -0.11 & 0.31 \\
C & -0.02 & -0.07 & -0.03 & -0.03 & 0.15 & -0.06 & $\mathbf{0 . 1 8}$ & -0.07 & 0.07 & 0.25 & -0.07 & 0.01 & 0.09 & 0.16 & 0.56 \\
SEV & -0.02 & -0.12 & -0.03 & -0.23 & 0.08 & -0.10 & 0.08 & $-\mathbf{0 . 1 7}$ & 0.05 & 0.01 & -0.18 & 0.01 & 0.06 & 0.08 & -0.50 \\
CC & -0.01 & -0.10 & -0.03 & -0.11 & 0.14 & -0.09 & 0.16 & -0.12 & $\mathbf{0 . 0 7}$ & 0.19 & -0.13 & 0.01 & 0.09 & 0.15 & 0.22 \\
$C_{i}$ & 0.01 & 0.02 & 0.01 & -0.07 & -0.13 & 0.02 & -0.16 & 0.03 & -0.05 & $\mathbf{- 0 . 2 7}$ & 0.01 & -0.01 & -0.07 & -0.14 & -0.85 \\
$E$ & 0.02 & 0.12 & 0.03 & 0.23 & -0.07 & 0.10 & -0.07 & 0.16 & -0.05 & -0.01 & $\mathbf{- 0 . 1 7}$ & -0.01 & -0.06 & -0.08 & 0.51 \\
$G_{s}$ & 0.02 & 0.11 & 0.03 & 0.15 & -0.14 & 0.10 & -0.14 & 0.14 & -0.07 & -0.15 & 0.15 & $-\mathbf{0 . 0 1}$ & -0.09 & -0.14 & -0.03 \\
GLU & 0.02 & 0.10 & 0.03 & 0.10 & -0.15 & 0.09 & -0.17 & 0.12 & -0.07 & -0.19 & 0.12 & -0.01 & $-\mathbf{0 . 0 9}$ & -0.15 & -0.25 \\
CHI & 0.02 & 0.08 & 0.03 & 0.05 & -0.15 & 0.07 & -0.17 & 0.09 & -0.07 & -0.24 & 0.09 & -0.01 & -0.09 & $-\mathbf{0 . 1 6}$ & -0.47 \\
Determination coefficient & & & & & & & & & & &
\end{tabular}

DZI - daidzin; GI - genistin; MD - 6"-O- malonyldaidzin; R - rutin; MG - 6"-O- malonylgenistin; C - coumestrol; SEV - severity; CHL chlorophyll; $C_{i}$ - internal $\mathrm{CO}_{2}$ concentration; $E$ - transpiration rate; $G_{s}$ - stomatal conductance to water vapor; $A$ - net CO2 assimilation rate; GLU - $\beta$-1.3-glucanase; $\mathrm{CHI}$ - chitinase. 
From the results reported here, other researches can be conducted to obtain genetic gains in these traits and may guide breeders on the genetic and physiological mechanisms of soybean defense against the $P$. pachyrhizi pathogen.

The application of methyl jasmonate reduced ASR drastically (Table III). Findings in this study are according to results reported in the literature which proved that methyl jasmonate can efficiently reduce diseases severity in many crops such as sweet cherry fruit (Yao and Tian 2005b), Alternaria brassicicola, Botrytis cinerea and Plectosphaerella cucumerina in Arabidopsis thaliana (Thomma et al. 2000), Monilinia fructicola in peach (Yao and Tian 2005a), Erysiphe necator in grapes (Belhadj et al. 2006) and Colletotrichum acutatum in plum (Cao et al. 2008).

Methyl jasmonate can reduce disease severity affecting fungal growth suppression as well as spores germination suppression, which both were reported for Alternaria alternata (Chen et al. 2014), and A. brassicicola in Arabidopsis thaliana (Thomma et al. 1998).

Another factor that should be considered is the increase of enzymatic activity with the methyl jasmonate application. According to Cruz et al. (2013) chitinase and $\beta$-1,3-glucanase are important to decrease the $P$. pachyrhizi colonization in soybean leaves tissue. These enzymes get involved to the plant defense against pathogen by the chitin and $\beta$-1,3-glucan hydrolytic action present on the fungal cell wall, and consequently the oligosaccharides liberation that may act as elicitors of the plant defense mechanism against fungal (Mohammadi et al. 2002). The overexpression of genes affecting chitinase and $\beta$-1,3-glucanase in plants have increased the resistant of plant for several pathogens (Van Loon 1997). Perhaps the enzyme activities increase favored the ASR severity reduction by methyl jasmonate application (Table III).
Despite that, there is no significant difference among treatments for photosyntetic parameters, plants treated with water had a slight decrease on them. Berger et al. (2007) proposed that plants reduce the photosynthesis and assimilation for increasing the respiration and other processes related with defense.

\section{PHENOTYPIC CORRELATIONS}

In a breeding program, knowledge about the relationship between variables is essential to achieve the desired genetic progress in the selection stages reducing cycle time and resources (Borém and Miranda 2013). In this work, we evaluated phenolic compounds content, enzymatic activity and photosyntetic parameters, which are difficult to measure and require high cost equipment and great demand for labor and time. Thus, estimates of phenotypic correlations reported here may guide physiologists and breeders about which selection strategies should be used in soybean. Besides that, a trait that has low $\mathrm{H}^{2}$ and/or greater difficulty of measurement can be evaluated indirectly with the measurement of another correlated variable (Cruz et al. 2012).

The large number of traits evaluated in this work provided 105 estimates of phenotypic correlations, and the interpretation of the correlation matrix is a difficult task. Thus, we sought to use the correlation network to graphically visualize the linear relationships between phenolic compounds content, enzymatic activity and photosyntetic parameters. The two-dimensional network allows to detect complex phenotypic patterns that are difficult to extract with other techniques (Figure 1). The efficiency of this innovative technique has already been reported in studies that evaluated a large number of metabolic compounds in tomato (DiLeo et al. 2011, Ursem et al. 2008).

In the correlation network, positive correlations were represented in green color and negative 


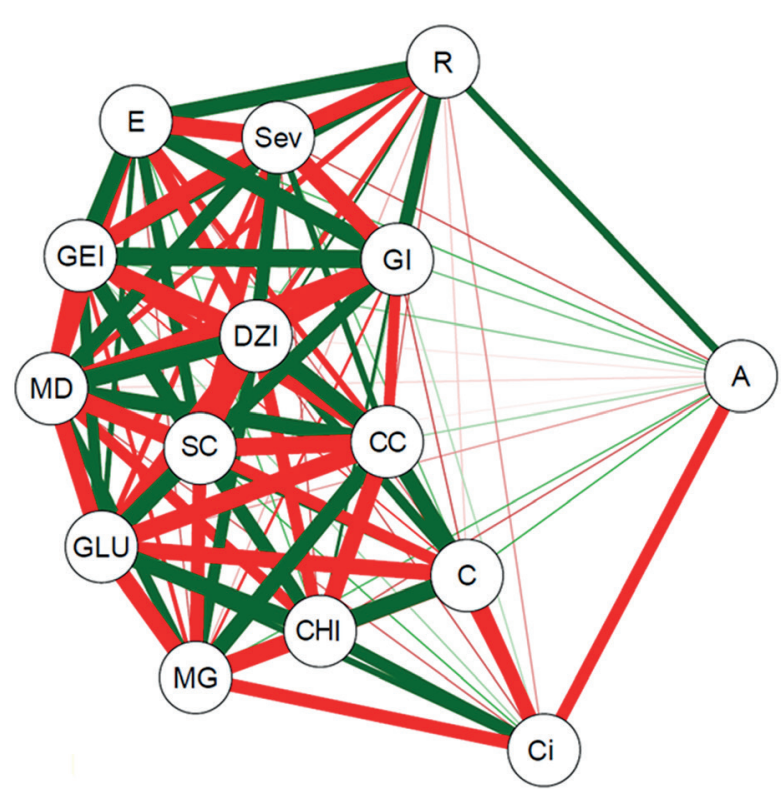

Figure 1 - Correlation network between the 15 traits evaluated in soybean plants inoculated with ASR: daidzin (DZI), genistin (GI), 6"-O- malonyldaidzin (MD), rutin (R), 6"O- malonylgenistin (MG), coumestrol (C), severity (Sev), chlorophyll (CC), $C_{i}$ - internal $\mathrm{CO}_{2}$ concentration; $E-$ transpiration rate; $G_{s}$ - stomatal conductance to water vapor; $A$ - net $\mathrm{CO}_{2}$ assimilation rate; $\beta$-1,3-glucanase (GLU), chitinase (CHI).

correlations in red. The greater was the thickness of the traces, the greater was the magnitude of the correlations. It was possible to observe a great association of the phenolic compounds content, enzymatic activity and photosyntetic parameters, except for $\mathrm{R}, C_{i}$ and $A$, that are further away at the ends of the two-dimensional network.

$A$ was the trait that smalest correlated with the others, presenting a positive linear relation with $\mathrm{R}$ and negative with $C_{i}$. The negative correlation between the traits $A$ and $C_{i}$ was also verified in other studies (Concenço et al. 2008, Ferreira et al. 2011) and indicates that when the photosynthetic rate is considered higher the $\mathrm{CO}_{2}$ concentration tends to be lower. It is important to highlight the evaluation of the $\mathrm{R}$, since this compound correlated negatively with SEV and positively with $A$. It has been reported by Hoffmann-Campo et al. (2006) that $R$ has a negative effect on the intake of soybean leaves by Anticarsia gemmatalis Hübner (Lep.: Noctuidae). However, there are still no reports on the negative effect of this compound on soybean diseases.

\section{PATH ANALYSIS}

Although important, the phenotypic correlation coefficient can produce misunderstandings about the relationship between two traits, and may not be an actual measure of cause and effect. $A$ high or low correlation coefficient between two traits may be the result of the effect that a third trait or a group of traits has on the pair, not giving the exact relative importance of the direct and indirect effects of these factors (Cruz et al. 2012). Therefore, we performed the path analysis, which investigates the cause and effect relationship. This analysis provides a detailed knowledge of the influences of the traits involved, and justify the existence of positive and negative correlations, of high and low magnitude, between traits.

However, to obtain the direct and indirect effects of path analysis, it is necessary a well conditioned matrix X'X. In the presence of multicollinearity, the variances associated to the path coefficient estimators can reach exceedingly high values, becoming unreliable. Besides that, the parameter estimates may assume no reasonable values or no coherence with the biological phenomenon (Cruz et al. 2012). One way to evaluate multicollinearity is the condition number, which results from the ratio of the largest to the smallest eigenvalue of the correlation matrix. According to the criterion presented by Montgomery et al. (2015), the matrix of estimates of phenotypic correlations showed a severe multicollinearity, since the condition number was higher than 1000. Thus, it was necessary to carry out the path analysis, through the inclusion of a constant $\mathrm{K}$ $=0.10$, in the diagonal of the correlation matrix.

The high estimates of the determination coefficients obtained when SEV and $A$ were considered as main dependent traits, besides 
low estimates of residual effect in both cases, show that almost all the variation in these traits can be explained by the other evaluated ones. These results are important because $A$ presented a low estimate of $\mathrm{H}^{2}$, besides being difficult to measure and to be subject to the variations of the environment. Although SEV has a high estimate of $\mathrm{H}^{2}$, it is extremely difficult to measure because it is established from scores and can become biased when more than one person performs the evaluations, which are common situations in soybean breeding programs.

For evaluating the direct effects of the path analyzes performed it was verified that there was a high direct negative effect of SEV on $A$ and vice versa. This association was not identified by the correlation estimates and reiterates the importance of path analysis to verify the association between variables. The $\mathrm{CO}_{2}$ assimilation rate reduction in inoculated soybean plants may be due to the destruction of leaves tissues that caused yellowing and premature defoliation. However, we did not observed visual alteration during the evaluation period and no leaf blade abscission. According to Goellner et al. (2010) visual symptoms caused by $P$. pachyrhizi can be observed after five through eight days after inoculation, and consequently it may explain why it was not observed any symptoms since the evaluation period was from one to eight days after inoculation. Therefore, the most important hypothesis to explain the $\mathrm{CO}_{2}$ assimilation rate reduction could be the occurrence of any damage in the photosynthetic mechanism due to metabolic changes happen before visual changes.

It was possible to verify that $\mathrm{R}$ has direct effects of high magnitude on both traits (SEV and $A$ ). This relationship is translated into cause and effect, because $\mathrm{R}$ also correlated positively with $A$ and negatively with SEV. The negative relationship between SEV and $\mathrm{R}$ is due to since $\mathrm{R}$ can induce the hydrolysis of membrane phospholipids altering the barriers and permeability of cell membranes (Gazzoni et al. 1997).

$E$ also presented high correlation as direct effects on SEV and high $\mathrm{H}^{2}$, however, no correlation was observed between $E$ and $A$. These results demonstrate that $\mathrm{E}$ should be evaluated in segregating populations where selection will be performed for resistance to $P$. pachyrhizi. The indirect selection aims for increasing the photosynthetic efficiency of the genotypes can be performed by means of the evaluation of $C_{i}$, which has high correlation with $A$, and high $\mathrm{H}^{2}$. Situations where environment stress happens excitation energy increases, and then it exceeds the required content for photosynthesis metabolism (Asada 1999). The increase of excitation energy is associated with the $\mathrm{CO}_{2}$ assimilation rate decrease due to the reduction of stomatal conductance to water vapor and the increase of production of reactive oxygen species (Mateo et al. 2004). Reactive oxygen species induced stomatal closure, and consequently it can explain the stomatal conductance to water vapor reduced (Munemasa et al. 2007). According to Loehrer et al. (2008) that studied the interaction between P. pachyrhizi and Arabidopsis observed that inoculated plants accumulated hydrogen peroxide which may be influenced the stomatal closure. The stomatal closure influences the $\mathrm{CO}_{2}$ influx decrease, and consequently in the lack of losses in the water vapor via transpiration. This fact may cause damage when plants are infected by fungus due to the need of assimilates for plant defense plus the extra drain which are the pathogenic agents (Berger et al. 2007). On the other hand, the stomatal closure when plants are infected by fungus is a strategy used by plants to avoid the pathogenic agents penetration through the stomata (Gudesblat et al. 2009). This strategy may be useful since the most etiologic agents that causes rust use the stomata to start the infectious process. Unfortunately, this strategy is not useful for $P$. pachyrhizi due to the penetration by this 
fungal occurs directly in the epidermis (Goellner et al. 2010), or rarely by guard cells in the stomata (Magnani et al. 2007).

Based on results reported here, no trait was shown to be promising for the indirect selection of genotypes with high photosynthetic efficiency and resistant to P. pachyrhizi. However, this research will contribute with future work aimed at the establishment of selection indexes in order to obtain multiple gains in SEV and $A$ in soybean plants.

\section{CONCLUSIONS}

Methyl jasmonate was efficient to reduce ASR effects on soybean plants.

The occurrence of ASR affects directly and with high magnitude traits related to enzymatic activity, phenolic compounds content and photosyntetic parameters in soybean, reducing the concentration of some traits and increasing in others.

The management of ASR is important to maintain the photosynthetic rates carried out by the plant at normal levels, and thus not affect the soybean yield at the end of the reproductive cycle.

\section{ACKNOWLEDGMENTS}

This work was supported by Coordenação de Aperfeiçoamento de Pessoal de Nível Superior (CAPES), Conselho Nacional de Desenvolvimento Científico e Tecnológico (CNPq), Fundação de Amparo à Pesquisa do Estado de Minas Gerais (FAPEMIG), Fundação Arthur Bernardes (Funarbe) and Universidade Federal de Viçosa for financial support. We also thank the Laboratório de Biometria (Universidade Federal de Viçosa, Brazil) where all analyses were performed by remote access.

\section{REFERENCES}

ASADA K. 1999. The water-water cycle in chloroplasts: scavenging of active oxygens and dissipation of excess photons. Annu Rev Plant Biol 50: 601-639.

BELHADJ A, SAIGNE C, TELEF N, CLUZET S, BOUSCAUT J, CORIO-COSTET MF AND MÉRILLON
JM. 2006. Methyl jasmonate induces defense responses in grapevine and triggers protection against Erysiphe necator. J Agr Food Chem 54: 9119-9125.

BERGER S, BENEDIKTYOVÁ Z, MATOUŠ K, BONFIG K, MUELLER MJ, NEDBAL L AND ROITSCH T. 2007. Visualization of dynamics of plant-pathogen interaction by novel combination of chlorophyll fluorescence imaging and statistical analysis: differential effects of virulent and avirulent strains of $P$. syringae and of oxylipins on $A$. thaliana. J Exp Bot 58: 797-806.

BORÉM A AND MIRANDA GV. 2013. Melhoramento de Plantas. Viçosa: UFV.

BRADFORD MM. 1976. A rapid and sensitive method for the quantitation of microgram quantities of protein utilizing the principle of protein-dye binding. Anal Biochem 72: 248-254.

BROWSE J. 2009. Jasmonate passes muster: a receptor and targets for the defense hormone. Annu Rev Plant Biol 60: 183-205.

CAO S, ZHENG Y, YANG Z, TANG S, JIN P, WANG K AND WANG X. 2008. Effect of methyl jasmonate on the inhibition of Colletotrichum acutatum infection in loquat fruit and the possible mechanisms. Postharvest Biol Tec 49: 301-307.

CHEN J, ZOU X, LIU Q, WANG F, FENG W AND WAN N. 2014. Combination effect of chitosan and methyl jasmonate on controlling Alternaria alternata and enhancing activity of cherry tomato fruit defense mechanisms. Crop Prot 56: 31-36.

CONAB - COMPANHIA NACIONAL DE ABASTECIMENTO. 2017. Companhia Nacional de Abastecimento - safra 2016/2017.

CONCENÇO G, FERREIRA E, SILVA A, FERREIRA F, GALON L, REIS M, D'ANTONINO L, VARGAS L AND SILVA L. 2008. Fotossíntese de biótipos de azevém sob condição de competição. Planta Daninha 26(3): 595-600.

CRUZ CD. 2013. GENES - a software package for analysis in experimental statistics and quantitative genetics. Acta Sci-Agron 35: 271-276.

CRUZ CD, REGAZZI AJ AND CARNEIRO PCS. 2012. Modelos biométricos aplicados ao melhoramento genético. Viçosa: UFV, 514 p.

CRUZ MFAD, RODRIGUES FÁ, POLANCO LR, CURVÊLO CRDS, NASCIMENTO KJT, MOREIRA MA AND BARROS EG. 2013. Inducers of resistance and silicon on the activity of defense enzymes in the soybean-Phakopsora pachyrhizi interaction. Bragantia 72: 162-172.

DILEO MV, STRAHAN GD, DEN BAKKER M AND HOEKENGA OA. 2011. Weighted correlation network analysis (WGCNA) applied to the tomato fruit metabolome. PLoS ONE 6: e26683.

DORRANCE A, MCCLURE S AND ST. MARTIN S. 2003. Effect of partial resistance on Phytophthora stem rot 
incidence and yield of soybean in Ohio. Plant Dis 87(3): 308-312.

FEHR WR, CAVINESS CE, BURMOOD DT AND PENNINGTON JS. 1971. Stage of development descriptions for soybeans, Glycine max (L.) Merrill. Crop Sci 11: 929-931.

FERREIRA EA, ASPIAZÚ I, GALON L, CONCENÇO G, SILVA AF AND REIS LAC. 2011. Características fisiológicas da soja em relação a espécies de plantas daninhas. Revista Trópica-Ciências Agrárias e Biológicas $5: 39$.

GAZZONI DL, HÜLSMEYER A AND HOFFMANNCAMPO CB. 1997. Efeito de diferentes doses de rutina e de quercetina na biologia de Anticarsia gemmatalis. Pesq Agropec Bras 32: 673-681.

GODOY CV, KOGA LJ AND CANTERI MG. 2006. Diagrammatic scale for assessment of soybean rust severity. Fitopatol Bras 31: 63-68.

GOELLNER K, LOEHRER M, LANGENBACH C, CONRATH U, KOCH E AND SCHAFFRATH U. 2010. Phakopsora pachyrhizi, the causal agent of Asian soybean rust. Mol Plant Pathol 11: 169-177.

GUDESBLAT GE, TORRES PS AND VOJNO AA. 2009. Stomata and pathogens: Warfare at the gates. Plant Signal Behav 4: 1114-1116.

HARMAN GE, HAYES CK, LORITO M, BROADWAY RM, DI PIETRO A, PETERBAUER C AND TRONSMO A. 1993. Chitinolytic enzymes of Trichoderma harzianum: purification of chitobiosidase and endochitinase. Phytopathology 83: 313-318.

HOFFMANN-CAMPO CB, RAMOS NETO JA, OLIVEIRA MCND, AND OLIVEIRA LJ. 2006. Detrimental effect of rutin on Anticarsia gemmatalis. Pesq Agropec Bras 41: 1453-1459.

LEVER M. 1972. Anew reaction for colorimetric determination of carbohydrates. Anal Biochem 47: 273-279.

LOEHRER M, LANGENBACH C, GOELLNER K, CONRATH U AND SCHAFFRATH U. 2008. Characterization of nonhost resistance of Arabidopsis to the Asian soybean rust. Mol Plant Microbe In 21: 14211430.

MAGNANI EBZ, ALVES E AND ARAÚJO DV. 2007. Eventos dos processos de pré-penetração, penetração e colonização de Phakopsora pachyrhizi em folíolos de soja. Fitopatol Bras 32: 156-160.

MATEO A, MÜHLENBOCK P, RUSTÉRUCCI C, CHANG CCC, MISZALSKI Z, KARPINSKA B, PARKER JE, MULLINEAUX PM AND KARPINSKI S. 2004. Lesion Simulating Disease 1 is required for acclimation to conditions that promote excess excitation energy. Plant Physiol 136: 2818-2830.

MILLER GL. 1959. Use of dinitrosalicylic acid reagent for determination of reducing sugar. Anal Chem 31: 426-428.

MOHAMMADI M, ROOHPARVAR R AND TORABI M. 2002. Induced chitinase activity in resistant wheat leaves inoculated with an incompatible race of Puccinia striiformis f. sp. tritici, the causal agent of yellow rust disease. Mycopathologia 154: 119-126.

MONTGOMERY DC, PECK EA AND VINING GG. 2015. Introduction to linear regression analysis. New Jersey: John Wiley \& Sons.

MUNEMASA S, ODA K, WATANABE-SUGIMOTO M, NAKAMURA Y, SHIMOISHI Y AND MURATA Y. 2007. The coronatine-insensitive 1 mutation reveals the hormonal signaling interaction between abscisic acid and methyl jasmonate in Arabidopsis guard cells. Specific impairment of ion channel activation and second messenger production. Plant Physiol 143: 1398-1407.

ROBERTS WK AND SELITRENNIKOFF CP. 1988. Plant and bacterial chitinases differ in antifungal activity. Microbiology 134: 169-176.

RUIZ-GARCIA Y AND GÔMEZ-PLAZA E. 2013. Elicitors: a tool for improving fruit phenolic content. Agriculture 3: 33-52.

SEO HS, SONG JT, CHEONG JJ, LEE YH, LEE YW, HWANG I, LEE JS AND DO CHOI Y. 2001. Jasmonic acid carboxyl methyltransferase: a key enzyme for jasmonate-regulated plant responses. P Natl A Sci 98: 4788-4793.

THOMMA BP, EGGERMONT K, BROEKAERT WF AND CAMMUE BP. 2000. Disease development of several fungi on Arabidopsis can be reduced by treatment with methyl jasmonate. Plant Physiol Bioch 38: 421-427.

THOMMA BP, EGGERMONT K, PENNINCKX IA, MAUCH-MANI B, VOGELSANG R, CAMMUE BP, AND BROEKAERT WF. 1998. Separate jasmonatedependent and salicylate-dependent defense-response pathways in Arabidopsis are essential for resistance to distinct microbial pathogens. P Natl A Sci 95: 1510715111 .

URSEM R, TIKUNOV Y, BOVY A, VAN BERLOO R AND VAN EEUWIJK F. 2008. A correlation network approach to metabolic data analysis for tomato fruits. Euphytica 161: 181-193.

USDA - UNITED STATES DEPARTMENT OF AGRICULTURE. 2017. World Agricultural Supply and Demand Estimates. United States Department of Agriculture, $40 \mathrm{p}$.

VAN LOON L. 1997. Induced resistance in plants and the role of pathogenesis-related proteins. Eur J Plant Pathol 103: 753-765.

VENCOVSKY R AND BARRIGA P. 1992. Genética biométrica no fitomelhoramento. Ribeirão Preto: Sociedade Brasileira de Genética.

WRIGHT S. 1923. The theory of path coefficients a reply to Niles's criticism. Genetics 8: 239-255.

YAO H AND TIAN S. 2005a. Effects of a biocontrol agent and methyl jasmonate on postharvest diseases of peach fruit 
and the possible mechanisms involved. J Appl Microbiol 98: 941-950.

YAO H AND TIAN S. 2005b. Effects of pre-and post-harvest application of salicylic acid or methyl jasmonate on inducing disease resistance of sweet cherry fruit in storage. Postharvest Biol Tec 35: 253-262.
YORINORI JT, PAIVA WM, FREDERICK RD, COSTAMILAN LM, BERTAGNOLLI PF, HARTMAN GE, GODOY CV AND NUNES JR J. 2005. Epidemics of soybean rust (Phakopsora pachyrhizi) in Brazil and Paraguay from 2001 to 2003. Plant Dis 89: 675-677. 